\title{
BIRDS OF GUJARAT UNIVERSITY CAMPUS, AHMEDABAD
}

\section{Nayan K. Jain, Samir N. Patel and Maulik V. Patel}

Department of Zoology, University School of Sciences, Gujarat University, Ahmedabad, Gujarat, India

Email:zooldeptgu@satyam.net.in

Urban biodiversity has received very little attention from conservation biologists as compared to natural and protected ecosystems (Jules, 1997; Vandermeer, 1997). Patvarthan et al. (2000) have identified educational and defense premises as hotspots for urban biodiversity. Although educational premises occupy less than $5 \%$ of the total urban area, such areas may harbour up to half the biodiversity of the urban biota (Patvarthan et al., 2000).

Gujarat University $\left(23^{\circ} 01^{\prime}-23^{\circ} 02^{\prime} \mathrm{N} \& 72^{0} 32^{\prime}-72^{0} 33^{\prime} \mathrm{E}\right)$ is situated in the city of Ahmedabad in Gujarat state. The whole area under study is refered to as Gujarat University Campus (GUC), which covers a large area and includes the main university campus, university hostels, as well as academic and research institutions such as ATIRA (Ahmedabad Textile Industries Research Association) campus, L.D. Arts College, L.D. Engineering College, L.M. College of Pharmacy and M.G. Science Institute.

The area experiences extreme variations in temperature, which ranges from maximum of $47^{\circ} \mathrm{C}$ in summer to a minimum of $4^{\circ} \mathrm{C}$ in winter. The summer is hot and dry, which is subsequently followed by a humid rainy season. During winter, the temperature falls to $4^{\circ} \mathrm{C}$. The minimum relative humidity has been recorded during the late winter months and ranges from $6 \%$ to $13 \%$ and maximum during the monsoon in July and ranges from $95 \%$ to $98 \%$.

The distribution and occurrence of avifauna correlate well with the vegetation patterns of the area, which is of great significance. The vegetation found in this area mainly consists of naturally grown trees and shrubs. The study area supports a number of native as well as exotic floral species. The GUC has rich vegetation comprising of 215 species of 171 genera belonging to 63 families (Joshi, 1997). The GUC also has a very large botanical garden. A large number of tall trees and indigenous fruiting trees occur in this area, which attract many birds (Wadatkar, 2000). Almost all these plants provide some cover and food for the birds throughout the year. The vegetation is dominated by large trees like Azadirachta indica, Acacia leucophloea, Acacia nilotica, Prosopis cineraria, Caesalpinia pulcherrima, Delonix regia, Cassia fistula, Ficus benghalensis, Ficus religiosa and Ailanthus excelsa (Chavan, 1993). Checklists of avifauna of the educational premises, cities, states and protected areas of state and country (Rathinasabapathy \& Kalairasan, 1992; Kasinathan et al., 1995; Inskipp et al., 1996; Padate \& Sapana 1996; Thirumurthi, 1997; Goswami, 1999; Oswin, 1999; Mohan, 2000; Mahabal, 2000;
Michael et al., 2000; Palot \& Pramod, 2000; Rathore \& Sharma, 2000; Sivaperuman \& Jayson, 2000; Ramitha \& Vijayalaxmi, 2001) have been compiled. The present study is focused not only on preparing the checklist of birds, but also to find out their occurrence, status as well as to create an awareness for their conservation. In addition, the study aims at providing the basic information of the avifauna for further studies related to campus biodiversity. This is the only large green spot in the city, where the birds can get cover. Hence the area should be wisely used without disturbing the activity of the birds and instead encouraging more number of species in the area.

Materials and methods: The work was carried out for a period of more than a year from July 2002 to August 2003. The birds were observed during the most active period in the day, mornings (0600 to 1000 hours) and late afternoons (1630 to 1900 hours). Sightings were carried out for two days a week during all seasons of the year to encounter maximum birds in an area. Moreover, superficial sighting was carried out everyday at the main spots during the morning and evening hours every day. The identification of birds and their occurrence were noted using a $7 \times 35$ binocular. Birds sighted during the study period were categorized according to their status as residents (R) (birds that have been known to breed in the study area itself and encountered during every visit), and local migrants (LM) (birds which were encountered many times during the study period and breeding in surrounding areas). Some birds sighted occasionally during specific season of study period, which are not resident of study area, are included as migrant birds (M). Bird identification followed Ali and Ripley (1983), Coomber (1991), Ali and Ripley (1996), Ali (1996), and Grimmett et al. (1999).

Based on the frequency of sighting in the field visits, the birds species are categorized as: Abundant (A): Birds sighted throughout the study area in good number during every visit (95\% -100\% encounter); Common (C): Sighted throughout the study site during most of the visit $(60 \%-95 \%$ encounter); Occasional (O): Found in small numbers and with less frequency of sighting (20\% - 60\% encounter); Rare (R): Frequency of sighting and numbers are very low (less than $20 \%$ encounters).

Observations: The GUC supports a good number of avifauna as it has a rich and varied vegetation pattern and possesses small water bodies. The GUC (260acres) comprises of different vegetation patterns that include scrubland, dense shrub vegetation with scattered trees, open garden vegetation with sparse trees, wetlands, and open degraded grounds and buildings.

A total number of 85 species of birds belonging to 40 families were observed, which is comparable to any small reserve forest. However, the low diversity may be due to constant human activities within and around the study area. Bird diversity in some protected areas in Gujarat indicates the following: Shoolpaneshwar Wildlife Sanctuary - 173 species (Desai, 1996), Vansda National Park - 115 species (Singh et al., 2000), and Ratanmahal Wildlife Sanctuary - 147 species (Singh, 2002). The state of Gujarat hosts 479 bird species and contributes 39\% of 
India's total bird diversity (Singh, 2001). A bird watcher Mr. P.S. Thakker (GEER foundation) had carried out a field survey of birds of Ahmedabad in 1985 and found 206 birds species.

Among the total bird species observed in GUC, 67 (78.8\%) were residents, $14(16.5 \%)$ were local migrants and four $(4.7 \%)$ were migrants. Forty-three species $(50.5 \%)$ were abundant, 20 $(23.5 \%)$ were common, $16(18.8 \%)$ were occasional and six $(7.1 \%)$ were rare.

The major influencing factor on the composition and distribution of bird species is the direct human intervention. The diversity recorded in such a human impacted area must not mislead one to those of large green parks and reserves in urban areas, as they support high species diversity because these protected urban areas are the habitat fragments of highly diverse ecosystem (Schaefer, 1994) while most of the urban habitats are unable to sustain their own biota and they often get the diversity from surrounding less impacted areas.

There are large number of thorny trees and thickets, which support a good number of avifauna. The study site possesses small water bodies in many numbers resulting mainly due to water overflow from the buildings and rain that supports water birds in the site. It was found that the occurrence of avifauna was significantly varied according to the vegetation patterns and anthropogenic pressure. The study site is rich in avifauna but problems have arisen recently as the habitat of these birds are threatened, due to unplanned activities being carried out in favour of human development, for which the thickets of the area have been cleared. Birds are sensitive to the local landscape and change in vegetation patterns can affect the population of birds in the area (Sauvjot et al., 1998; Savard et al., 1999). Such a rare green spot should be managed well to attract more bird species and make the premises favourable for various birds.

\section{REFERENCES}

Ali, S. (1996). The Book of Indian Birds. 12 $2^{\text {th }}$ Edition. Oxford University Press, Delhi, 140pp.

Ali, S. and S.D. Ripley (1983). A Handbook of the Birds of India and Pakistan together with those of Bangladesh, Nepal, Bhutan and Sri Lanka. Compact edition. Oxford University Press, Delhi, 220pp.

Ali, S. and S.D. Ripley (1996). A Pictorial Guide to the Birds of the Indian Subcontinent. $2^{\text {nd }}$ Edition (update). Oxford University Press, Mumbai, 150pp.

Mohan, B.A. (2000). Birds in and around Sri Venkateshwara wildlife sanctuary, Andhra Pradesh. Zoos' Print Journal 15(10): 339-343.

Chavan, S.A. (1993). Vegetation and Wildlife Studies in Gir Forest. $\mathrm{Ph}$.D. Thesies submitted to M.S. University of Baroda, Vadodara.

Coomber, R. (1991). Birds of the World. Colour Library Books Ltd, Italy.

Desai, I.V. (1996). Studies on Avifauna and Avian Ecology of Shoolpaneshwar Wildlife Sanctuary. Ph.D. Thesis submitted to M.S. University of Baroda, Vadodara.

Goswami, S. (1999). Birds in Shivpuri Forest, Madhya Pradesh. Zoos' Print Journal 14(7): 75-76.

Grimmett, R., C. Inskipp and T. Inskipp (1999). Birds of the Indian subcontinent. Oxford University press, New Delhi, 344pp.

Inskipp, T., N. Lindsay and W. Duckworth (1996). An Annotated Checklist of Birds of the Oriental Region. Oriental Bird Club. UK.

Joshi, K.I. (1997). Flora of Gujarat University area. In: $2^{\text {nd }}$ Refresher, Department of Botany, Gujarat University, Ahmedabad.
Jules, E.S. (1997). Danger in dividing conservation biology and agro ecology. Conservation Biology 11: 1272-1273.

Kasinathan, S., M. Parthiban and S. Paulraj (1995). Birds of the Grizzled Giant Squirrel Wildlife Sanctuary, Srivilliputtur, Tamil Nadu. Zoos' Print Journal 10(5): 8-14.

Mahabal, A. (2000). Birds of Talra Wildlife Sanctuary in lower western Himalaya, H.P., with notes on their status and altitudinal movements. Zoos' Print Journal 15(10): 334-338.

Michael J.B., W.F. Davis, B.R. Mark and K.S. Brian (2000). A Field Cchecklist of the Birds of Guyana. Publication 41 of the Biological Diversity of the Guianas program, Smithsonian Institution, Washington, DC, USA.

Oswin, D. (1999). Avifaunal diversity of Muthupet Mangrove Forest. Zoos' Print Journal 14(6): 47-53.

Padate G.S. and S. Sapana (1996). Checklist of birds in and around Harni Pond, an urban wetland near Baroda. Pavo 34: 95-104.

Palot, J.M. and P. Pramod (2000). A checklist of birds of Calicut University Campus, Kerala. Zoos' Print Journal 15(2): 214-216.

Patvarthan, A., S. Nalavade, Saharsabuddhe and G. Utkarsh (2000). Urban wildlife from Nero's fiddle to Noah's arch - A report. Published by RANWA, Pune.

Ramitha, M. and K. Vijayalaxmi (2001). A Checklist of birds in and around Mangalore University Campus, Karnataka. Zoos' Print Journal, 16(5): 489-492.

Rathinasabapathy, B. and V. Kalairasan (1992). Birds of National Zoological Park. Zoos' Print 7(8): 33.

Rathore, V. and R.K. Sharma (2000). Avifauna of a lake in district Etawah, Uttar Pradesh, India. Zoos' Print Journal 15(6): 275-278.

Sauvjot, R.M., M. Buechner, D.A. Kamradt and C.M. Schonerwald (1998). Patterns of human disturbances and response by small mammals and birds, in chaparral near urban development. In: Urban Ecosystem 2: 279-297.

Savard, L.J., P. Clergeau and G. Mennechez (1998). Biodiversity concept and urban ecosystem. Landscape and Urban Planning 48: (34) pp 131-142.

Schaefer, V. (1994). Urban Biodiversity in Biodiversity, pp. 307-308. In: Harding, L.E. and E.O. Mccullum (Eds.) British Columbia. Environment Canada and Canadian Wildlife service, Vancouver, Canada. Singh H.S. (2002). Biodiversity Study in Ratanmahal Wildlife Sanctuary, 8: $90-104$.

Singh, H.S. (2001). Natural Heritage of Gujarat. Gujarat Ecological Education and Research (GEER) Foundation, Gandhinagar, 47pp.

Singh, H.S., B.R. Rawal, Patel, B.H., Tatu, K. Patel and R. Vyas (2000). Biodiversity Study on Vansda National Park (A Comprehensive ecological and socio-economic study). GEER Foundation, Gandhinagar. Sivaperuman, C. and E.A. Jayson (2000). Birds of Kole wetlands, Thrissur, Kerala. Zoos' Print Journal 15(10): 344-349.

Thirumurthi, S. and S. Balaji (1997). Avifauna of the Forest College and Research Institute Campus, Mettupalayam, Tamil Nadu. Zoos' Print Journal 12: 24-26.

Vandermeer, J. (1997). The Agro Economics System. A need for the conservation-biologist's lens. Conservation Biology 11: 591-592.

Wadatkar, J.S. (2001). Checklist of birds from Amaravati University Campus, Maharashtra. Zoos' Print Journal 16(5): 497-499.

\section{ACKNOWLEDGEMENTS}

The author wishes to express their gratitude to Dr. U.M. Rawal (Zoology Department, Gujarat University) for critical assessment and Dr. H.N. Highland, Zoology Department, Gujarat University for reviewing the manuscript. We are also thankful to Mr. P.S. Thakkar (GEER foundation) for providing valuable information for the birds present in the Ahmedabad environment. 
Table 1. Checklist of birds found in and around Gujarat University Campus

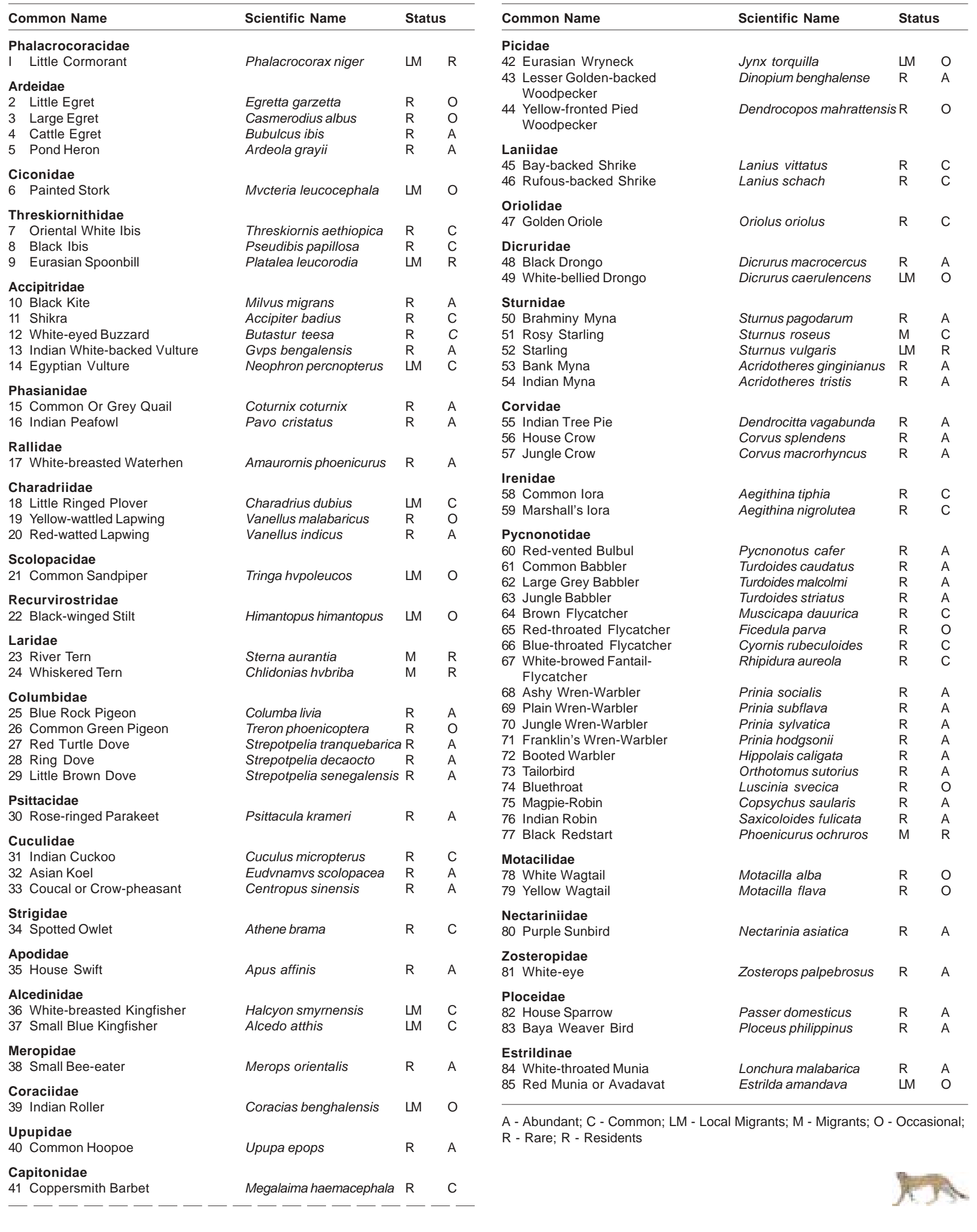

